\title{
"If He/She Had Been Like the Rest of Us". How Do Young People Describe Their Schoolmates Who Are Different from Others in the Group?
}

\author{
Minna Saarinen ${ }^{1} \&$ Satu Mattila ${ }^{1}$ \\ ${ }^{1}$ Faculty of Educational Sciences, University of Helsinki, Finland \\ Correspondence: Minna Saarinen, Faculty of Educational Sciences, 00014 University of Helsinki, Finland. Tel: \\ 358-50-318-5660.
}

Received: July 1, 2018

Accepted: August 3, $2018 \quad$ Online Published: September 6, 2018

doi:10.5539/jel.v7n6p1

URL: https://doi.org/10.5539/jel.v7n6p1

\begin{abstract}
The article examines issues related to peer interactions and group joining in upper secondary schools in Finland. The study elaborates on how young people describe students who are left out/excluded or who remain outside the social networks. The study also elucidates on how a student can join the group. The research is motivated by the current educational ethos, which emphasizes inclusion and tolerance. The data were collected from an upper secondary school and vocational and technical institute. The students were asked to recall the prior high school year and write an essay on the topic. A total of 49 students wrote about their memories. The data were analyzed using inductive content analysis, and the study found that students are either excluded or included due to the social skills they possess. Those who do not exhibit the same approach to being in a group will stay on the sidelines. The essays also described factors that connect students, such as hobbies and leisure activities. Similarity in many external factors (e.g., the family's economic situation) unites students. Contrary to expectations, young people described themselves, and not just others, as outsiders.
\end{abstract}

Keywords: inclusive school, diversity, youth, peer relationships, sense of exclusion

\section{Introduction}

\subsection{Peer Relationships Among Youth}

The article examines issues related to young people's peer interactions and group joining in upper secondary schools. The acceptance of others, friendships and peer groups are important for young people both in developmental and emotional terms (Hartup, 1992; Paulo, 2006; Korkiamäki, 2014, p. 38). The youth years are the time of creation of identity and self-image (Lehtinen, Kuusinen, \& Vauras, 2007, p. 26). Identity is mainly formed in a social context, which in adolescence usually means a peer group (Lehtinen et al., 2007, p. 27). Their coevals are the most important reference group for young people (Berger, 2011, p. 443) not only for building a self-image, but also for the development of a world view (Korkiamäki, 2014). Kiuru (2008) describes friendships as things that generate social support, security, trust, solidarity, and emotional engagement. When moving away from parents and developing responsibility for one's own life happens to young people, usually with the support of their friends (Paulo, 2006, p. 60).

In high school, the disapproval of friends can lead the young to believe that they have something wrong (Shaffer, 1996, p. 319, O’Brien \& Bierman, 1988, pp. 1362-1364, Graham \& Juvonen, 2001). If group joining fails, the value of the relationship is invalidated, and the young person can become isolated and / or start showing psychological symptoms (Hietala et al., 2010, p. 58; Paulo, 2006, p. 61). Svahn and Evaldsson (2011) have illustrated that unnoticeable exclusion practices are more devastating for young people than direct forms of physical bullying. The development of the excluded young person is endangered in many ways. Not only can social skills remain weak and the risk of psychological problems increases, but loneliness can predispose somatic diseases (Løhre et al., 2014, p. 3). Being alone in adolescence brings risks for both mental health and future life (Korkiamäki, 2014, pp. 38-39). Friendships are the pillars of healthy development that help learning and developing social skills. Loneliness leaves the young in a state in which they cannot share their experiences, reflect on things with peers or get direct feedback on their behavior (Korkiamäki, 2014, pp. 38-39.) Youth loneliness is pathological according to Harinen (2008) and it is subject to the risk of social exclusion. A school 
health survey has revealed that around $10 \%$ of upper secondary and vocational school students experienced loneliness (School health survey, 2017). Loneliness means being left alone and experiencing solitude, which is not always a personal choice (Hietala et al., 2010, p. 46). Saari (2010) describes loneliness as being a social phenomenon that seriously hampers wellbeing. Youth loneliness is related to negative factors such as feelings of sadness and depression, dissatisfaction, intentional self-harm, and in case of girls, a dislike of school (Rönka, 2017; Hawkley \& Cacioppo, 2010). Between 10 and 15 per cent of school-aged people feel chronically lonely, and almost 45 percent feel somewhat milder loneliness over the years and girls experience loneliness more often than boys (Laine, 2005, p. 166). According to Tallgren (2013, p. 5), one in ten adolescents experiences loneliness.

\subsection{Students' Diversity at School}

In the basics of the primary education curriculum $(2014$, p. 13) diversity is one of the values of the Finnish school. Diversity is linked to culture, Finnishness, time, different genders, etc., and highlighted as a positive feature. Diversity is also a concept that emerges in inclusion discussions. In earlier times, the starting point for directing students into special education was the individuality and idiosyncratic characteristics of students, whereby some students have been taught separately from others in separate setting, in segregation (Ahvenainen, Ikonen, \& Koro, 1999, p. 16). In the inclusive school, the situation is different. Inclusion contains the requirement for learning together. "Learning together, over linguistic, cultural, religious and viewing boundaries creates the preconditions for genuine interaction and communality," is stipulated in the National Core Curriculum for Basic Education (2014, p. 16). The inclusive school challenges schools to consider new ways of creating friendship and relationships among young people and group activities. The objective of the inclusive school is to ensure equal opportunities for all children and young people to learn and study and become community members (United Nations, 1994; Parliament, 2016; UNESCO, 1994; Ainscow, Booth, \& Dyson, 2006, pp. 11, 27; Kuorelahti, Lappalainen, \& Viitala, 2012, p. 277). In this article, diversity refers to the whole spectrum of youth, even though it is often associated with culture or sexuality (see Culture for all, 2015).

The most common reasons why a young person remains excluded from his or her peer group are related to behavior (Saarinen, 2012, p. 152; Saarinen, 2013, p. 13). Young people may have difficulty controlling their feelings and impulses, or they may be silent and withdrawn (Junttila, 2010, p. 34; Saarinen, 2012, p. 160-162). Disorders and disabilities can pose challenges for joining peer groups (Løhre et al., 2014). Experiences of loneliness or self-chosen solitude are also related to lack of school enjoyment (Kyllönen et al., 2017). It has been found that students with poor school achievements have difficulty to make friends, but the best performing students also had similar problems (Myllyniemi, 2009, p. 83). There are risk factors that may influence exclusion. The social structure has various limitations but rejects other limitations and obstacles. Some obstacles are more demanding (e.g. violent or aggressive behavior) than others (e.g. stubbornness). Thus the environment selects the obstacles (Saarinen, 2012, p. 182).

Often what must be examined is how the loneliness of a young person or the scarcity of their friends is considered disturbing and causing embarrassing situations (Määtä \& Tolonen, 2011, p. 29). On the other hand, exclusion can also be seen as a resource when it is self-selected. A young person may want to be distinguished from the group and live according to their own ideology, even if it leads to exclusion. The young person may build an included position in other groups. However, deviating from the mainstream requires not only strength but the environment should also enable it. On the other hand, the loneliness of a young person may be due to their own withdrawal, difficulties in establishing contact with others and desire to be alone. Having a serious mental disorder may also be the reason for seeking solitude (Junttila, 2015, p. 39).

The research questions are: 1) How do young people describe a student who is excluded from the group? 2) What are the prerequisites for joining a group?

\section{Research Method}

\subsection{Participants}

The data were collected from 49 students from two schools. They were second year students from upper secondary school and vocational school students who were between 17 and 20 years of age. Thirty-one of the respondents were students from upper secondary school (girls 19 and boys 12) and 18 were vocational school students (girls 8 and boys 12) who were experienced in essay writing in terms of age and academic experience. The participants had experience of the phenomenon and at this age, they already had the skills to analyze the situations experienced at a metacognition level. In addition, their prior high school year was a recent memory. 


\subsection{Data Collection}

The volunteers $(\mathrm{N}=49)$ wrote an essay on the topic "Group exclusion and its related factors and ways to join the group as experienced by young people". This way, young people were able to handle a sensitive subject anonymously and without losing face. The essays were written during a lesson and were extensive descriptive texts containing 254 words on average. The vocational school students' essays were shorter. The essay was a recollection of how individuals define themselves (Kangas, 1997). In this study, the method of recollection (see Haug, 1987) was applied and participants outlined their own memories, but did not actually examine themselves or interpret their texts. The handwritten essays were later written as a Microsoft Word document and the material was 32 pages long and contained 7877 words. The font size was 12 and the line spacing 1.15.

\subsection{Analysis}

The data were analyzed using inductive content analysis (Patton, 1990), proceeding from individual statements towards general theoretical concepts. The data were read several times (Bogdan \& Biklen, 1992, pp. 153-183). The participants were given their own IDs (LT1 = high school girl number 1 and AKP2 = vocational school boy number 2). The original statements were shortened and listed separately. They were thoroughly reviewed for consistent conceptual content, grouped and named according to the concepts describing them. The statements that were similar in meaning were grouped into subcategories. The grouping was continued by combining subcategories of the same content into upper categories and further into main categories (see Marton, 1981). The analysis and classification of data have a strong link to the concepts used in special education.

\subsection{Reliability and Ethics}

We used the criteria for reliability presented by Tynjälä (1991). The conformity was shown by the fact that the research environment was familiar, and the students were given sufficient trust/confidence in the data collection phase. The data were collected from students who wanted to participate in the research. The results are transferable because the essay writers represented different types of schools and only a short time had passed since their last high school year.

The reliability of the material is decreased by its relatively small size. Conversely, the reliability of the research was based on the use of researcher triangulation (Laine, Bamberg, \& Jokinen, 2007), i.e. two authors. The data were reviewed several times during the analysis. The method triangulation could have enhanced the reliability if we had interviewed the students. This would have made possible the comparison of data collected in different ways. All the material was anonymized. School descriptions were also left out. Permission was obtained from the principals and the teachers of lessons when the essays were written. Students were also asked for permission and permission from parents of minors was obtained through Wilma, (electronic web interface for school-home communication)

\section{Findings}

The young people described from different perspectives students at group who were excluded. Contrary to expectations, they described themselves, and not just others, as outsiders and external observers. The observations of students in upper secondary school and in vocational education were mostly similar.

\subsection{Quiet, Ordinary Looking and Aggressive Young People Differentiate from Others}

According to Korkiamäki (2014), the exclusion does not necessary require social marginalization, social exclusion or special education status. In this study, when young people described their excluded classmates, they somehow suspected that they had some diagnosis or that they should have been in a smaller class. Some of the youngsters who were left out of the group had changed to a small class or their classmates knew that they had been offered such possibility. Behavior that deviated from normal behaviors attracted young people's attention and caused withdrawal from interaction. They characterized such a person as "strange" or "irritating". Young people differentiated someone who deviates from students in the mainstream group (Korkiamäki, 2014,p. 40). As criteria for differentiation, they considered physical features and emotional skills. Students recognized a social stigma in accordance with the medical model and acted accordingly. They seemed to characterize this stigma as a problem (see Niemi, 2015, p. 358). In this study, information about a classmate's diagnosis and its measures ( $=$ transfers from one group to another) resulted in social withdrawal, exclusion and differentiation. We conclude, as did Paju (2011, p. 101), that school structures produce social multipath in school life where students show each other's places in the social structure of the school.

In our class in high school there was one boy. He was very different, he was very sensitive and easily annoyed and his feelings were on the surface constantly. He was also very big and clumsy. Our whole class shied away ... The boys in the class had a disgusting way to irritate him deliberately by commenting, 
mocking, "playing" stealing his things. A few times he was furious to the point he beat them up and ran away, and he did not appear at school for the next two weeks. (LT 18)

The material outlined a picture of a different young person, one excluded from the group because his social skills are inadequate. He could behave inappropriately in interactions, for example, intruding on others or irritating them. Also, the silent and introverted behavior was described as a negative feature. The occasional aggressive behavior was often linked to silence and withdrawal. Students" behavior was viewed as "weird" and they were avoided. Young people assumed that they would change their behavior when they noticed that others did not accept it. They thought that appropriate behavior was a condition for joining the group. The youngsters created opportunities for an outsider to rejoin the group, even though it was dictated by specific terms. We assume that students expect social order in the classroom. This means that the students know the rules and act accordingly. Abnormal behavior or silence and withdrawal violate class norms, of which Heritage (1996, p. 120) speaks as a reflective awareness of one's own actions.

He was quiet, in general, but when he said something, it was often something negative about others ... He was also very aggressive at times, which was also one of the things that pushed people in our class away from him. He did not change the whole year, we adapted to the situation and let the school days continue. Eventually he went to a special education group. (LT 7)

Young people hone and refine each other by giving feedback on both behavior and appearance. Problems arise if recipients do not understand the feedback they receive or are not able to act as expected. This increases the reporting and explaining situations within the group and might even bring sanctions (Heritage, 1996, p. 89).

I completely lack the ability to speak to strangers, I cannot just go and introduce myself and begin speaking naturally. I can only do that when I feel relaxed with a person. On the other hand, I am also sometimes weird, and all members of the group were very ordinary and similar in appearance. It was very difficult for me to come up with something to talk about. (LT 18)

Silence and shyness promoted exclusion which young people interpreted as a deliberate desire to be alone. The silent ones were left in their own peace to be responsible for the contacts they established. If a young person was a bystander, she or he was completely excluded. Everyone has a responsibility for their own position in the group. Although young people can use initiatives and hints in integrating someone back into the group, in practice, it does not seem to be a common way of thinking among them (see Saarinen \& Takala, 2016, p. 40). An inclusive school could welcome all its members to the school community and encourage participation (see Doyle 2008 , p. 4). This means using different means to increase the involvement and inclusion of all students.

If I wanted to join the group, I should be louder and more social. I should have taken more care of my appearance and party on the weekends and become, at least in my opinion, much more superficial. I cannot tolerate such a thing, so if I' $m$ not good when being myself, then nothing can be done. At the beginning of $7^{\text {th }}$ grade I had no friends and I did not know anyone. I sat alone and it felt pretty bad, but I was finally joined by one person and with this guy I became a bit more social and got more friends. (LT 13)

Creating a friendship with outsiders is more challenging because of the risk of stigmatization and falling victim to exclusion. It is therefore difficult for a person different from the mainstream group to get a friend who can help them to join the group. Friendships seemed to be mainly with students in the same situation, a similar person or with a group member of presumably high status. A group member of high status does not have to worry about falling out of the group when choosing their friends and thus has the opportunity to make friends with a person of lower status as well.

The youths found three categories that are relevant to deviation from the main group. The interviewees described this through seeing themselves as being different or describing others who are different from the community. Young people who were different from a group were not considered to be members of this community and for various reasons; they were unable to accept the rules and values of the group or community (Paju, 2011, p. 46). In addition, these young people lacked good social skills; they were either very introverted and shy students or had aggressive and offensive behaviour (Saarinen, 2012).

Students' understanding of the school is generally good; they have adopted the school culture and know what a good learner is in the organization (see Kiilakoski, 2012; Lahelma \& Gordon, 1997). Students also recognize the school's way of selecting students and assigning them a place. Its background is a medical psychological, medical thinking model that classifies and maintains a special student status and a need for special education services. The essence of the model is that difficulties are seen as students' characteristics. McLaren (1993) emphasized that schools are trying to reduce the behavioral extremes of the young people who come to it. 


\subsection{Youth's Dilemma: Similar, Different, Unique}

Differentiation from the group is avoided even if it means abandoning one's own style or opinion (cf. Salmivalli, 2004, p. 139). Group membership guarantees friendships and inclusion. Harinen (2008) described how young people who know how to behave "right" in a group get most friends and the best status,

The distinctive personality and differentiation from the group seem to influence exclusion. Everyone should always follow the same fashion. Slightly different clothes or different colored hair, especially among girls, are associated with exclusion. The behavior should always be adaptable and flexible. There must always be the same opinions and one must accept all things and events. The personality should be too kind and keeping one's rights is not allowed. Distinction from the crowd is scary. (AKT 3)

Young people admitted they appreciated their friends who had remained "true to themselves" even though the class community had initially been cautious about them. This was usually a new and quiet student, or a self-confident "free spirit" with good social skills. Common hobbies and a friendly, pleasant nature would resolve the situation in their favor even though they did not agree to be altered in line with the pressures of the environment. At least in one's own group of friends, such courage is rewarded and appreciated for staying "true to oneself". Some had a controversial attitude towards diversity. The findings revealed a picture of a young person who respected differences deep down. Korkiamäki (2014) explained that "free spirits" know how to position themselves outside the mainstream.

I do not think anyone should start to change themselves to get into the group. However, I believe that today many require a "normal" dress style. There are "strangely" dressed and "normally" dressed. That is, the appearance, unfortunately, has a big role. (LT 15)

The requirement for similarity assumption seems to require a change by those who are different. Only through change it would be possible for them to become members of the group. Friend groups usually consist of quite similar young people who bring forward a collective identity (Perho, 2010; Salmivalli, 2005, p. 139). Korkiamäki (2016, p. 37) describes youth by means of similarity and ordinality.

Some of the young people thought of a group in terms of its similarity, its expectations and values. According to Salmivalli (2005, pp. 138-144), the process is bi-directional. Young people are looking for groups whose values or interests are suitable and similar to their own interests. The group will shape the youths and being together will strengthen common standards. Young people may have difficulty getting into the group they want to be in because of their aggressiveness. The most significant effect of a group or friend is when a young person pursues membership or friendship without a response (Salmivalli, 2005, p. 153).

He would have been able to get into the group if he had behaved a little wisely and had not said something annoying all the time. Instead, he tried to get closer to the guys by pretending to be tough, so he started smoking cigarettes and talk smack, which did not really make the situation better but actually worse, because now everyone thought he was annoying and no one wanted to be with him because of his behavior. (AKP 6)

The truth was that he was placed in the Mclass (for disabled students) at the beginning of high school, but he had not agreed to go there although most of his friends were there. Changing to the Mclass could have made things easier because students would have been more tolerant and more understanding than in the normal class. (LT18)

The essays explained how young people should have friends like them to become happy. Being in a wrong group without friends did not bring feelings of happiness. Korkiamäki (2014) described this outsider's position as being one'sown choice. It is not imposed but is self-directed and chosen, as young people do not always find soulmates in the group. In that case, it may be their choice to stay outside. Self-selected and voluntary exclusion could also be described as self-sufficiency (Harinen, 2008).

Young people's groups seem to be homogeneous, so it may be difficult for someone different from the mainstream to join them- even if they change. Positions are dictated by the young people themselves, although access to them can be re-defined and gained (Korkiamäki, 2014, p. 42). If a young person distinct from the group has at least one friend, with his or her support, it is possible to get accepted (Saarinen, 2012). Friendship and the moral awakening of the community can help to change the atmosphere. Acting to influence the situation requires relatively high status and good self-confidence. Saarinen \& Takala (2016) describe how the responsibility of making the initiative lies with all group members. Courage and freedom of choice were associated with being initiative. It is the positive social pressure that has a greater influence on the behavior of young people than pressure on negative behavior (Salmivalli, 2005, p. 152). 
Generally, the reason for discrimination has been that someone dares to be oneself and separates from the crowd. I just appreciate and like such people, because difference is more than good. Own opinions should be expressed, and everyone should be able to dress in clothes that feel comfortable and exquisite, for example. I have not seen or noticed any discrimination because I always take everyone in and try to defend the weaker. The only event I recall now was when one of my friends was dressed in slightly different clothes from the rest. Many began commenting on her style, but I did point them out the inappropriateness of such comments and I went away with this friend. (LT 3)

In the essays of the girls studying in a small town, immigrant background emerged as a distinctive factor for exclusion, both as a personal experience and as an example seen in the group.

I decided that I had to force myself and start talking to others, because I cannot assume that someone would just become my buddy. I became more social, I got friends from other classes, but mostly from my own class. I became a friend of all thanks to becoming social. Both boys and girls were my friends. If I did not push myself then, I think I would not have friends, would be un happy and would not enjoy the school at all. At that time, in my class there was a boy who did not like me, and it showed. I have an ethnic background and it was wrong and stupid of him. So, I sometimes suffered for something I cannot influence. That's not fair! (LT 7)

In the writings of vocational school students, immigrant background was never mentioned, even though there are many immigrants in the area. On the other hand, there are already many second-generation immigrants, so children and young people have been meeting with friends from different cultures since daycare. Our findings are neutral, even positive, since often researchers have found the opposite (Zacheus et al., 2017a, p. 7). Also, for example, Räsänen and Kivirauma (2011, p. 88) found that in multicultural schools, bullying is more common in schools with more immigrant students. On the other hand, it is claimed (Zacheus et al., 2017b, p. 10, under evaluation) that ethnicity is unlikely to be discussed because it is difficult for people to show what they really are. The differences between upper secondary school students and vocational students in this case could therefore be explained by the effect of the environment rather than the form of education. School location, secondary education and gender have been shown to make a difference between young people's experience and behavior in previous studies (Luopa et al., 2014; Hämäläinen, Juutilainen, \& Hellsten, 2007, pp. 47-50; Tolonen, 2001; Paju, 2011, p. 284).

\subsection{Factors Supporting Peer Interactions}

In this study, peer relationship factors can be divided into three main categories: external factors, behavior- and temperament-related factors, and adults' support.

The external factors include common interests and hobbies, which give young people things to talk about and shared leisure time. Cotterell (2007) described how the everyday life of young people is shaped by their membership in diverse and changing groups. The answers from the girls clearly differed from those of the boys. The attitudes towards substance abuse and its effects on social relations were seen to be the opposite in the girls' and boys' responses. The use of intoxicants by boys was seen as a positive, facilitating interaction factor, while girls' experiences of friends using intoxicants were negative. Korkiamäki (2013) describes how the stigmatization of a particular group leads to exclusion from the young mainstream community.

My best friend began to hang out with strange people and his former friends rejected him. He started using drugs and lost many good friends. He began drug rehabilitation and was utterly bereft. If he had understood to stop and stay with his friends, he would still have them. He should have just stopped using drugs from the start. (AKT 2)

Material things and wealth were also related to external factors.

I've been left out from hanging out with friends a few times because I do no town a scooter or moped car. Sometimes we've been on the field kicking the ball and then somebody suggested going to McDonald's. Because I do not have a scooter or car, and no one wants to give a lift, I go home. Our bond with the guys is really tight, but sometimes I feel a bit of an outsider because we do not have much money and I cannot always afford what they can. (LP11)

Parents' wealth or desire to get their children fashionable clothes, consumer goods, or sports equipment facilitated the access to a group. Hygiene and good self-care were also emphasized in the students' writings. Tolonen (2009) describes how young people use friends as promotors of their own well-being. Kimm et al. (1995) also claim that care of appearance, hygiene and clothing can make and promote social relationships, since the young person has then shown respect for others thought their own appearance. The admission into the group 
was also influenced by clothing and appearance. Compliance or non-compliance with the dress code was considered and its violation could cause social sanctions.

Similarity related to way of dressing and weight facilitated group joining. Hoikkala and Paju (2013, pp. 87-88) and Saarinen (2012) also found that young people feel a strong demand to dress in the same way. The type of clothes used rather than brands was more significant. If the student's status in the classroom was high enough, they could afford to wear more unusual clothing. Hoikkala and Paju (2013, pp. 87-88) suspected that in case of students with weaker status this could have led to bullying, but for those at higher hierarchical levels, this was a way of expressing their distinct personality. Ordinary clothing makes users remain unnoticed and conventional at school (Tolonen, 2001, p. 170).

Young people noticed an unusually dressed classmate and initially he received negative feedback. The situation however turned positive when criticism provoked reactions. A friend could defend him, or the student defended his own style, despite the pressure, and eventually received appreciation and be accepted into the group without any demands to change.

She did not change her style of dressing but stood behind her choices and refused to comply with others' opinions. However, the group quickly became accustomed to her style and nowadays there is no more staring and no remarks. (LT 3)

Behavior- and temperament-related factors that supported interaction and group joining were described extensively as generally positive features by young people. Some of the tangible behavior factors mentioned were talking and courage to approach and join others. The answers clearly outlined a picture of an extrovert, relaxed class "bosses" and a happy friend, compliant with the common opinions that can also control the expression of his opinions.

Often group behavior was guided by a class "boss" or bunches of smaller group "bosses" and adapting to their actions seemed to guarantee a place in the group and facilitate friendship and relationships with members of the core group, especially among girls.

A student with special education needs and somebody from an immigrant background may have challenges to meet the requirements for similarity. According to Tolonen (2001 p. 260), even slight differences in behavior or clothing may lead to bullying. Young people define themselves as ordinary to merge easily into a group. Nowadays, with increasing immigration and inclusion, student societies are becoming increasingly heterogeneous, and schools and curricula have had to respond and adapt to that. Schools are expected to be more prepared to accept a wider range of students. In the upper secondary school there are still no support measures to help excluded students create social relationships (Tolonen, 2001).

Social competence refers to the ability to act reciprocally and sensitively in a situationally-appropriate manner. Hoikkala and Paju (2013, pp. 146-147) found that the ninth-grade students who they studied, especially the girls, had a tendency to form "core groups" in their classes, and many were willing to "do everything" to get into them. The group's glory and characteristics were transferred to the young along with the membership. A group member could also be displaced by an interesting newcomer. Disagreements could also destroy the whole group, where each member's status and position changed and the search by each for their own place could start again. (Hoikkala \& Paju, 2013, pp. 146-147).

\subsection{Group Support}

When coming to a new class, a young person may initially stay or be left alone. The respondents described how a new student was left out of the group and he was 'invisible' to the others who already had their own friends. Young people expect a newcomer to take the initiative bravely, and if he or she does not, they can easily become an outsider. In such situations, the new student can be integrated and introduced to others by a classmate he already knows.

Usually when I come into a new class and I hardly know anyone, I stay aside. I sit alone in class when others group and acquire new friends. I am quiet and shy so it's not helping the situation much. But after all, I get at least one friend out of the crowd when I finally approach somebody similar. (LT 13)

Courage and an active attitude in contact-taking have been highlighted (see Saarinen \& Takala, 2016). This was generally required from both sides. Studies indicate that at least one student in a group must have the role of an initiator to integrate a new or an excluded student into the group. Souto (2011, p. 58) describes this with the concept of social initiative.

One essay depicted a situation in which class support and receptive attitude positively influenced the group 
joining and increased the self-confidence of the newcomer.

He became a little closer to us. I have to point out that he was not discriminated against, he was just alone. Probably the classmates began paying attention to him being alone. As soon as the issue had been discovered and he also noticed the others' desire to get acquainted with him, he could be a little more relaxed. He himself did not change, but his self-confidence grew. (LT 16)

Changing classes requires a lot from the young. They should be suitably outgoing, take up contact with old classmates, and be able to choose a suitable group for themselves. According to Junttila (2015, pp. 96-97), at the beginning of secondary school, it is important to create at least one friendship during the first half of the year. After that, those alone usually remain alone, regardless of their social skills (Junttila, 2015, pp. 96-97).

\section{Reflections and Observations: Involvement as a Prerequisite for an Inclusive School: Ways to Create Inclusion}

This study reports on an examination of peer interactions and group joining of students of upper secondary school age. It also elaborates on how young people describe excluded students and how joining a group can be facilitated. The young people who participated in the study shared their thoughts on students different from the group or left out of it, describing similarity requirements between friends, such as clothing, appearance, material things, but also their values. The group studied appreciated personality and the courage to be oneself, however with some limits. The existence of peer groups implies emotional belonging and common features and boundaries that place other young people outside the community. The boundary was most clearly set for differences in behavior or thinking. Young people preferred to choose a friend with whom they were able to exchange ideas at the same level and whose behavior was predictable.

Aggressive behavior was avoided, and interaction was discontinued. This was accompanied by a strong demand to change behavior before being accepted in the group. Tolonen (2001, p. 201) describes a situation in which aggressiveness and inability to control one's behavior were seen by young people to be a significant factor in isolation from the group. Special pedagogy utilizes many ways to deal with aggression. One way to prevent aggressive behavior is to practice social and emotional skills in the classroom (Hakala, 2014, p. 19). The anti-bullying program "Kiva Koulu" (2017) is currently the most widely used program for practicing emotional and social skills in Finland. The ART (aggression replacement training ${ }^{\circledR}$ ) method used to address aggressive and anti-social behavior. Its exercises strengthen the self-regulatory skills of young people and generate moral reflections (Maukonen, 2014). The "Responsibility for Injustice" program directs young people to take responsibility for their actions, while NOTE tries to increase cooperation in and outside school (Hotulainen et al., 2010).

The essays identified the pupils who should have been in a different group, e.g. special education. Acceptance was given to education in small (often segregated) special education groups some who need it. The essays also contemplated why some did not accept the small group they were offered. According to our observations, young people have accepted the school's way of segregating or selecting and classifying their students exclusively. This creates a dilemma through which the school organization is exclusive, and today's requirement is an inclusive school. This is where the medical and the disability social models collide (see Grue, 2011). In a medical explanation model, disability, learning difficulty, or other need for special support is seen as an individual's pathological feature and individuals need support for their abnormality, deficiency or illness. In this model, it is important to identify and diagnose deviation in order to be rehabilitated (see Oliver, 1996, Shakespeare, 2006).

In high school, facing diversity should belong to teaching. Inclusion cannot be achieved solely by physical implementation or focusing on the organization of teaching. Ethical considerations and awareness of what it means to remain alone and what it can lead to; can help young people understand their responsibilities as members of a community. Teachers and schools should be aware of the risk factors and think beforehand of the steps to break the negative spiral.

If a teacher has information on group dynamics, opinion triggers and attitudes, it would be easier to influence what happens in the social context of the class. Again, this requires an open atmosphere and discussion between the class. The especially quiet and those who have joined the class in the middle of the school year will be in the danger zone of being left alone if they are not supported and encouraged to join the group. It would be a good idea to raise the awareness of high school teachers about the diversity of students and the challenges it poses for class grouping and division and grouping support methods (Maukonen, 2014, p. 22; Hoikkala \& Paju, 2013, p. 14). In addition, we need to understand the main goal of inclusiveness - to support the peer relationships of all students and their involvement in group activities. According to Mikola (2012), inclusion provides the opportunity to grow in one's community. This involves the question of equality and justice, which means that 
everyone must be oneself and be accepted as such. Schools need change, which also entails renewal and improvement of teaching. Guidance of heterogeneous groups requires a multidisciplinary co-operation between teachers. Facing students' diversity in school and treating people equally are topical issues in Finnish society today.

\section{References}

Ahvenainen, O., Ikonen, O., \& Koro, J. (1999). Erityispedagogiikka 2. Erityiskasvatuksen käytäntö. [Special pedagogy 2. Special education methods]. Juva: WSOY.

Ainscow, M., Booth, T., \& Dyson, A. (2006). Improving schools, developing inclusion. London: Routledge.

Berger, K. S. (2011). The Developing person through the life span (8th ed.). New York Worth Publishers.

Bogdan, R., \& Biklen, S. K. (1992). Qualitative research for education. An introduction to theory and methods (2nd ed). Boston: Allyn \& Bacon.

Cotterell, J. (2007). Social Networks in Youth and Adolescence (2nd ed.). London: Routledge.

Culture for all. (2015). Retrieved May 27, 2015, from http://www.kulttuuriakaikille.fi/moninaisuus_mita_on_moninaisuus

Doyle, M. B. (2008). The paraprofessional's guide to the inclusive classroom. Working as a team. Baltimore: Paul. H. Brookes.

Graham, S., \& Juvonen, J. (2001). An attributional approach to peer victimization. In J. Juvonen \& S. Graham (Eds.), Peer harassment in school: the plight of the vulnerable and victimized (pp. 49-72). New York: Guilford Press.

Grue, J. (2011). Discourse analysis and disability: Some topics and issues. Discourse \& Society, 22(5), 532-546. https://doi.org/10.1177/0957926511405572

Harinen, P. (2008). Good, bad loneliness. Selfishness, loneliness and friendship in the late modernism. In M. Autio, K. Eräranta, \& S. Myllyniemi (Eds.), Polarizing youth? Young people's living conditions - an yearbook (pp. 84-93). Helsinki: Youth Research Network / Youth Research Society, publications 84.

Hartup, W. W. (1992). Friendships and their developmental significance. In H. McGurk (Ed.), Childhood social development. Contemporary perspectives (pp. 175-205). East Sussex: Lawrence Erlbaum.

Hawkley, L. C., \& Capioppo, J. T. (2010). Loneliness matters: A theoretical and empirical review of consequences and mechanisms. Annals of behavioral medicine: A Publication of the Society of Behavioral Medicine, 40(2), 218-227. https://doi: 10.1007/s12160-010-9210-8

Heritage, J. (1984/1996). Garfinkel and Ethnomethodology. Helsinki: Gummerus.

Hietala, T., Kaltiainen, T., Metsärinne, U., \& Vanhala, E. (2010). Youth and mind: school support in mental health. Helsinki: Tammi.

Hoikkala, T., \& Paju, P. (2013). Apina pulpetissa: Ysiluokan yhteisöllisyys. [Monkey at the desk - Ninth grade community]. Helsinki: Gaudeamus.

Hotulainen, R., Kuorelahti, M., \& Lappalainen, K. (2010).Children and young people's socio-emotional difficulties - what can help? Retrieved from http://wanda.uef.fi/tkk/projektit/sosemot/puuttuminen.php

Junttila, N. (2010). Social competence and loneliness in schoolchildren. In K. Joronen \& A. Koski (Eds.), Enhancing emotional and social skills in the school community (pp. 34-38). Tampere: Tampere University Press.

Junttila, N. (2015). Zero friends. Children and young people's loneliness. Helsinki: Tammi.

Kiilakoski, T. (2012). The school as seen and experienced by young people. Situation evaluation November 2012. The National Board of Education's memo 6. Retrieved from http://www.oph.fi/download/144743_Koulu_nuorten_nakemana_ja_kokemana_2.pdf

Kimm, C. H., Falvey, M. A., Bishop, K. D., \& Rosenberg, R. L. (1995). Motor and personal care skills. In M. A. Falvey (Ed.), Inclusive and heterogenous schooling. Assessment, curriculum, and instruction (pp. 187-228). Baltimore: Paul. H. Brookes.

Kiuru, N. (2008). The Role of Adolescents' Peer Groups in the School Context. Jyväskylä Studies in Education, Psychology and Social Research 331. Jyväskylän yliopisto.

KiVa Koulu. (2017). Retrieved December 29, 2017, from http://www.kivakoulu.fi/ 
Korkiamäki, R. (2013). KAVERIA EI JÄTETÄ! Sosiaalinen pääoma nuorten vertaissuhteissa.[LEAVE NO FRIENDS BEHIND! Social capital in youth relations]. (Doctoral dissertation). Tampere: University of Tampere.

Korkiamäki, R. (2014).’'If I could get friends now"-Exclusion in peer relationships as experienced by young people. In M. Gissler, M. Kekkonen, P. Känkänen, P. Muranen, \& M. Wrede-Jäntti (Eds.), Youth in other words-young people's living conditions yearbook 2014 (pp. 38-50). Helsinki: THL, Youth Research Network, Youth advisory board.

Korkiamäki, R. (2016). Friendship as Potential? The Recognition of Teenagers' Peer Relationships at school. Open Journal of Social Sciences, 4, 34-43. https://dx.doi.org/10.4236/jss.2016.49005

Kuorelahti, M., Lappalainen, K., \& Viitala, R. (2012). Socio-emotional competence and inclusion experience. In M. Jahnukainen (Ed.), Children's special care and teaching in Finland (pp. 277-297). Tampere.

Kyllönen, S., Hirvonen, R., Ahonen, T., \& Kiuru, N. (2017). Loneliness, self-withdrawal and parental beliefs in connection with early schoolchildren's wellbeing at school. NMI-Bulletin, 27(3), 25-39.

Lahelma, E., \& Gordon, T. (1997). First Day in Secondary School: Learning to Be a "Professional Pupil". Educational Research and Evaluation, 3(2), 119-139. https://doi.org/10.1080/1380361970030202

Laine, K. (2005). Me, we, and the others in the social networks. Helsinki: Otava Publishing Company.

Laine, M., Bamberg, J., \& Jokinen, P. (2007). Case study—practice and theory. In M. Laine, J. Bamberg, \& P. Jokinen (Eds.), Case studies (pp. 9-40). Helsinki: Gaudeamus.

Lehtinen, E., Kuusinen, J., \& Vauras, M. (2007). Educational Psychology. Helsinki: WSOY.

Luopa, P., Kivimäki, H., Matikka, A., Vilkki, S., Jokela, J., Laukkarinen, E., \& Paananen, R. (2014). Youth's wellbeing in Finland 2000-2013. School health survey results. THL, Report: 25/2014.

Løhre, A., Kvande, M. N., Hjemdal, O., \& Lillefjell, M. (2014). A two-year perspective: who may ease the burden of girls' loneliness in school? Child and Adolescent Psychiatry and Mental Health, 8(1), 1-15. https://link.springer.com/article/10.1186/1753-2000-8-10

Marton, F. (1981). Phenomenography-describing conception of the world around us. Instructional Science, 10, 177-200. https://doi.org/10.1007/BF00132516

Maukonen, M. (2014). ART - aggression management method for practicing social skills and emotional control. eEriKa, 1, 20-22.

McLaren, P. (1993). Schooling as a ritual performance. Towards a political economy of educational symbols \& gestures (2nd ed.). London \& New York: Routledge.

Mikola, M. (2012).Criteria for inclusion and learning together. Lectio Praecursoria. NMI_Bulletin, 22(1), 4-9.

Myllyniemi, S. (2009). Free time, research on young people's leisure 2009. Helsinki: Youth research network / Youth research society, Publications 92 \& Youth advisory board, publications 40 \& Ministry of Education $\&$ Youth research society.

Määttä, M., \& Tolonen, T. (2011). Given, taken, self-made. Helsinki: Youth research network / Youth research society, publications 112 .

National core curriculum for Basic Education. (2014). National board of education. Retrieved from http://www.oph.fi/ops2016/perusteet

O’Brien, S. F., \& Bierman, K. L. (1988). Conceptions and Perceived Influence of Peer Groups: Interviews with Preadolescents and Adolescents. Child Development, 59(5), 1360-1365. https://doi.org/10.2307/1130498

Oliver, M. (1996).Understanding disability. From theory to practice. New York: Palgrave. https://doi.org/10.1007/978-1-349-24269-6

Paju, P. (2011). School should be completed. Ethnographic study of the classroom as a social premise. Helsinki: Youth research network / Youth research society, publications 115.

Parliament. (2016). Ratification of the Convention on the Rights of Persons with Disabilities. Retrieved from https://www.eduskunta.fi/FI/tietoaeduskunnasta/kirjasto/aineistot/kotimainen_oikeus/LATI/Sivut/vammaist en-oikeuksien yleissopimuksen - ratifiointi.aspx

Paulo, A. (2006). Youth among their peers. In E. Laukkanen, M. Marttunen, S. Miettinen, \& M. Pietikäinen (Eds.), Facing young people's psychological problems (pp. 59-64). Helsinki: Duodecim. 
Perho, S. (2010). Racism in the youth community. Research from the millennium phase in Joensuu. Helsinki: Youth research society / Youth research network, publications 103.

Räsänen, M., \& Kivirauma, J. (2011). A student in a multicultural school. In K. Klemelä, A. Tuitu, A. Virta, \& R. Rinne (Eds.), A guest at school? Multicultural school experiences of pupils, parents, teachers and principals (pp. 39-95). Educational sciences publications A: 211. Turku: University of Turku.

Rönka, A. R. (2017). Experiences of loneliness from childhood to young adulthood: study of the Northern Finland Birth Cohort 1986 (Doctoral dissertation). Oulu: University of Oulu.

Saari, J. (2010). Lonely society. Helsinki: WSOYpro.

Saarinen, M. (2012). Sosiaalisen elämän kehykset. Kampus-ohjelman opiskelijoiden sosiaalinen asema tuetussa aikuisopiskelussa ja vapaa-ajalla. [Social life framework. Campus-programme students' social position in supported adult learning and leisure time] (Doctoral dissertation). Jyväskylä: University of Jyväskylä.

Saarinen, M. (2013). The social position of young people diagnosed with developmental disabilities in supported $\begin{array}{lllll}\text { adult } & \text { learning. } & \text { Rehabilitation, } & \text { 6-17. }\end{array}$ https://kuntoutussaatio.fi/files/2077/kuntoutus-lehti-4-13-valmis.pdf

Saarinen, M., \& Takala, M. (2016). Drama as an inspiration for inclusion-an experiential learning process for young people. NMI-Bulletin, 3, 29-50.

Salmivalli, C. (2004). Young person in a peer group. Do birds of a feather flock together? Psychology, 39, 344-354.

Salmivalli, C. (2005). With friends. Peer relationships and social development. Jyväskylä: PS publishing.

Schaffer, H. R. (1996). Social development. Oxford: Blackwell.

School health survey time series. (2017). Retrieved from https://www.thl.fi/fi/web/lapset-nuoret-ja-perheet/tutkimustuloksia/kaikki-kouluterveyskyselyn-tulokset

Shakespeare, T. (2006). The social model of disability. In L. J. Davis (Ed.), The Disability studies reader. New York: Routledge.

Souto, A. M. (2011). Everyday racism in schools. Ethnographic study on group relations between Finnish and immigrant youth. Helsinki: Youth research network, Youth research society, publications 110.

Svahn, J., \& Evaldsson, A. C. (2011). "You could just ignore me": Situating peer exclusion within the contingencies of girls' everyday interactional practices. Childhood, 4(18), 491-508. https://doi.org/10.1177/0907568211402859

Tallgren, S. (2013). Loneliness can be prevented by many means. Mannerheim League for Child Welfare. Retrieved from http://mll-fi-in.directo.fi/(at)Bin/ed69266f58fed67c40a600c416bee05b/1385630443/application/pdf/184433 34/MLL-kaikille_kaveri_aukeamittain_lowres.pdf

Tolonen, T. (2001). Youth cultures in school. Sound, space and genre everyday arrangements. Helsinki: Gaudeamus Book.

Tolonen, T. (2009). Parents' absence and the social skills of young people. In M. Bardy (Ed.), At the heart of child welfare (pp. 144-156). Helsinki: Department of health and welfare.

Tynjälä, P. (1991). The reliability of qualitative research methods. Finnish educational science magazine. Education, 22(5-6), 387-398.

UNESCO. (1994). The Salamanca Statement and Framework for Action on Special Needs Education. Retrieved from http://www.unesco.org/education/pdf/SALAMA_E.PDF

UNITED NATIONS. (1994). Standard rules on the equalization of opportunities for persons with disabilities. Adopted by the United Nations general assembly at its 48th session on 20 December 1993 (resolution 48/96).

Zacheus, T., Kalalahti, M.,Varjo, J., Saarinen, M., Jahnukainen, M., Mäkelä, M-L., \& Kivirauma, J. (2017a). Experiences of discrimination, bullying and racism among high school students. Terra, 129(1), 33-15.

Zacheus, T., Kalalahti, M.,Varjo, J., Saarinen, M., Jahnukainen, M., Mäkelä, M-L., \& Kivirauma, J. (2017b). Discrimination, harassment and racism in Finnish lower secondary schools. Manuscript draft. Nordic Journal of Migration Research. 


\section{Copyrights}

Copyright for this article is retained by the author(s), with first publication rights granted to the journal.

This is an open-access article distributed under the terms and conditions of the Creative Commons Attribution license (http://creativecommons.org/licenses/by/4.0/). 